\title{
MERLUCCIUS HUBBSI (TELEOSTEI: MERLUCCIIDAE): STOCK IDENTIFICATION BASED ON REPRODUCTIVE BIOLOGY IN THE SOUTH-SOUTHEAST BRAZILIAN REGION
}

\author{
André Martins Vaz-dos-Santos ${ }^{1,2, *}$, Carmen Lúcia Del Bianco Rossi-Wongtschowski ${ }^{1}$ \\ and José Lima de Figueiredo ${ }^{3}$ \\ ${ }^{1}$ Instituto Oceanográfico da Universidade de São Paulo \\ (Praça do Oceanográfico, 191, 05508-120 São Paulo, SP, Brasil) \\ ${ }^{2}$ Universidade São Judas Tadeu - USJT \\ (Rua Taquari, 546, 03166-000 São Paulo, SP, Brasil) \\ ${ }^{3}$ Museu de Zoologia da Universidade de São Paulo \\ (Av. Nazaré, 481, 04263-000 São Paulo, SP, Brasil) \\ *Corresponding Author: amvaz@usp.br/prof.andre@usjt.br
}

\begin{abstract}
A B S T R A C T
The Argentine hake, Merluccius hubbsi, a demersal-pelagic species found from Rio de Janeiro, Brazil to the Tierra del Fuego, Argentina, has become an important target of the Brazilian bottomtrawler fleet since 2001. Earlier studies focusing on the species have suggested that more than one stock might occur off the Brazilian coast, in accordance with environmental features. In order to evaluate this hypothesis, fish were collected from four different areas in the Brazilian waters in which the hake is distributed, during the summers and winters of 1996-2001 and 2004, the females being used to analyze and compare spatial-temporal variations in ovarian maturation. Gonad indexes were also applied for the same purpose. Results indicate a north-south spawning gradient occurring as from summer at around $21^{\circ} \mathrm{S}$ to winter near $34^{\circ} \mathrm{S}$, leading to the identification of two distinct stocks: one located between $21^{\circ} \mathrm{S}$ and $29^{\circ} \mathrm{S}$ (Southeastern stock) and the other between $29^{\circ} \mathrm{S}$ and $34^{\circ} \mathrm{S}$ (Southern stock), this latter shared with Uruguay and Argentina. Brazilian stocks present clear signs of overexploitation, the situation calling for an urgent solution.
\end{abstract}

\section{RESUMO}

A merluza Merluccius hubbsi, espécie demerso-pelágica distribuída desde o Rio de Janeiro, Brasil, até a Terra do Fogo, Argentina, tornou-se alvo das frotas de arrasto de fundo da região Sudeste-Sul do Brasil desde 2001. Estudos anteriores sobre a biologia da espécie sugeriram a existência de mais de um estoque em águas brasileiras, relacionados a características ambientais. Para verificar esta hipótese, exemplares oriundos de quatro áreas em águas brasileiras foram coletados durante o verão $\mathrm{e}$ o inverno nos períodos 1996-2001 e 2004, sendo as fêmeas utilizadas para analisar variações espaçotemporais na maturação gonadal. Para corroborar estas análises também foram aplicados índices gonadais. Os resultados mostraram a ocorrência de um gradiente norte-sul para a desova, que é mais intenso no verão em $21^{\circ} \mathrm{S}$ e no inverno em $34^{\circ} \mathrm{S}$. Foram identificados dois estoques: um denominado Sudeste, que se distribui entre $21^{\circ} \mathrm{S}-29^{\circ} \mathrm{S}$, e outro Sul, entre $29^{\circ} \mathrm{S}-34^{\circ} \mathrm{S}$, este último compartilhado com o Uruguai e a Argentina. Os estoques brasileiros apresentam sinais de sobrepesca, situação que merece atenção e medidas apropriadas de gestão.

Descriptors: Merluccius hubbsi, Reproduction, Spawning, Stocks, Southeast-South Brazilian Region. Descritores: Merluccius hubbsi, Reprodução, Desova, Estoques, Sudeste-Sul do Brasil.

\section{INTRODUCTION}

The Argentine hake, Merluccius hubbsi Marini, 1933, is a demersal-pelagic species occurring in the southwestern Atlantic from $21^{\circ} \mathrm{S}$ (Brazil) to $55^{\circ} \mathrm{S}$ (Argentina) (FIGUEIREDO; MENEZES, 1978; MENEZES et al., 2003; COUSSEAU; PERROTTA, 2004). In Argentina and Uruguay, where it is a very

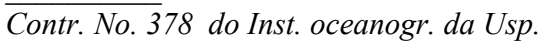


important commercial species (HART, 1948; COUSSEAU; JOHN, 1976; BELLISIO et al., 1978; OTERO, 1980; OTERO et al., 1981; REY; GRUNWALDT, 1986; CSIRKE, 1987; PODESTÁ, 1987; ALHEIT; PITCHER, 1995; REY; ARENA, 1999; AUBONE et al., 2000, 2004; BEZZI et al., 2004), its biology has been studied by authors ever since Angelescu et al. (1958). In Brazil, the larval distribution of the Argentine hake has been studied by Torres-Pereira (1983, unpublished), its feeding habits and reproduction by Haimovici et al. (1993), its general biology by Vaz-dos-Santos and RossiWongtschowski (2005), its reproduction by Vaz-dosSantos et al. (2005) and Honji et al. (2006), the occurrence of a shared stock with Uruguay and Argentina by Vaz-dos-Santos et al. (2006), its commercial landings by Perez and Pezzutto (2006) and its age and growth by Vaz-dos-Santos and RossiWongtschowski (2007). The most recent studies are a consequence of the abundance detected during the Brazilian Program for the Assessment of the Exclusive Economic Zone (REVIZEE Program, 1996-2006) (MMA, 2006) and because it has become a target species of bottom-trawlers since 2001 (PEREZ et al., 2003; VALENTINI ; PEZZUTTO, 2006).

Although a controversial subject, stock identification has been considered essential for the fishery sciences to provide for proper management of the species. Thus, Csirke (1980) gave support to population dynamics based on homogeneity of groups and Cadrin et al. (2005a) asserted that stock identification is a "prerequisite for the tasks of stock assessment and population dynamics". All considerations related to the management of fishery resources are based on the stock concept (GULLAND, 1983; HILBORN;WALTERS, 1992; BEVERTON;HOLT, 1993; SPARRE; VENEMA, 1998; QUINN; DERISO, 1999), including the most recent (KRUSE et al., 2005). The FAO's Code of Conduct for Responsible Fisheries (FAO, 1995) warns that only the best scientific data should be used for management, if the sustainability of the fisheries is to be ensured.

Stock identification has been formally discussed in the symposium "Stock identification - Its Role in Stock Assessment and Fisheries Management", held as a part of the $28^{\text {th }}$ American Fisheries Society's Meeting, in 1998. A special issue of the scientific journal Fisheries Research (vol. 43, 1999) was prepared based on the discussion of that symposium and some of its general conclusions deserve emphasis: (i) the term stock must obligatorily be applied to a homogeneous population unit and its management (BEGG; WALDMAN, 1999); (ii) a failure in stock identification can lead to its overexploitation (BEGG et al., 1999a) and (iii) genetic and/or environmental differences that persist over time are enough to separate stocks (SWAIN; FOOTE, 1999). After that meeting, Cadrin et al. (2005b) edited a book which discussed the subject, as a consequence of the studies conducted by the ICES Stock Identification Methods Working Group.

Regarding Merluccius hubbsi stocks in Uruguay and Argentina, three different groups have been detected between $34^{\circ} \mathrm{S}$ and $55^{\circ} \mathrm{S}$ (BEZZI; PERROTTA, 1983; CHRISTIANSEN et al., 1986; PERROTTA; SÁNCHEZ, 1992; GUTIÉRREZ et al., 1995; TORRES et al., 1996; SARDELLA; TIMI, 2004) and have been differentiated by means of various techniques.

On this theme, the identification of Merluccius hubbsi stocks along the Brazilian coast was first suggested by Vaz-dos-Santos and RossiWongtschowski (2005) and a detailed analysis of their reproduction is presented here as a tool for the differentiation of two stocks.

\section{Material and Methods}

Commercial landings of Merluccius hubbsi were obtained from bottom-trawls sampled between 1996 and 2001 and in 2004, complemented with survey samples obtained at the same time using similar fishing gear, at depths of between $40 \mathrm{~m}$ and $400 \mathrm{~m}$. The Southeast-South Brazilian coast was divided into four areas: $21^{\circ} \mathrm{S}-24^{\circ} \mathrm{S}(\mathrm{A}), 24^{\circ} \mathrm{S}-26^{\circ} \mathrm{S}(\mathrm{B})$, $26^{\circ} \mathrm{S}-29^{\circ} \mathrm{S}$ (C) and $29^{\circ} \mathrm{S}-34^{\circ} \mathrm{S}$ (D) (Fig. 1). Data were selected and analyzed specifically in summer (January, February and March) and winter (July, August and September) based on previous knowledge of the reproductive activity of the species (VAZ-DOSSANTOS; ROSSI-WONGTSCHOWSKI, 2005), a procedure also adopted earlier by Giussi et al. (1994) in Argentina.

Only females were selected and 533 specimens (LT from 164.00 to $618.00 \mathrm{~mm}$ ) were used for the analysis of their ovarian maturation, marked in accordance with Honji et al. (2006) who consider five reproductive stages based on detailed histological features: stage A - immature, stage B - maturing, stage $\mathrm{C}$ - mature, stage $\mathrm{D}$ - spawning, and stage $\mathrm{E}$ spent. The selection took into account the period (summer or winter), the four sample areas (A to D), $30 \mathrm{~mm}$ total length class and ovarian maturation stages. In this way, samples (LT) were statistically described (TRIOLA, 2005) and the minimum sample size $\left(\varepsilon=0.05 ; \mathrm{t}_{(2), \alpha=0.05}\right)$ was calculated in accordance with Gulland (1966), reinforced by Sparre and Venema (1998), to verify the statistical sufficiency of the data for the subsequent analysis. 


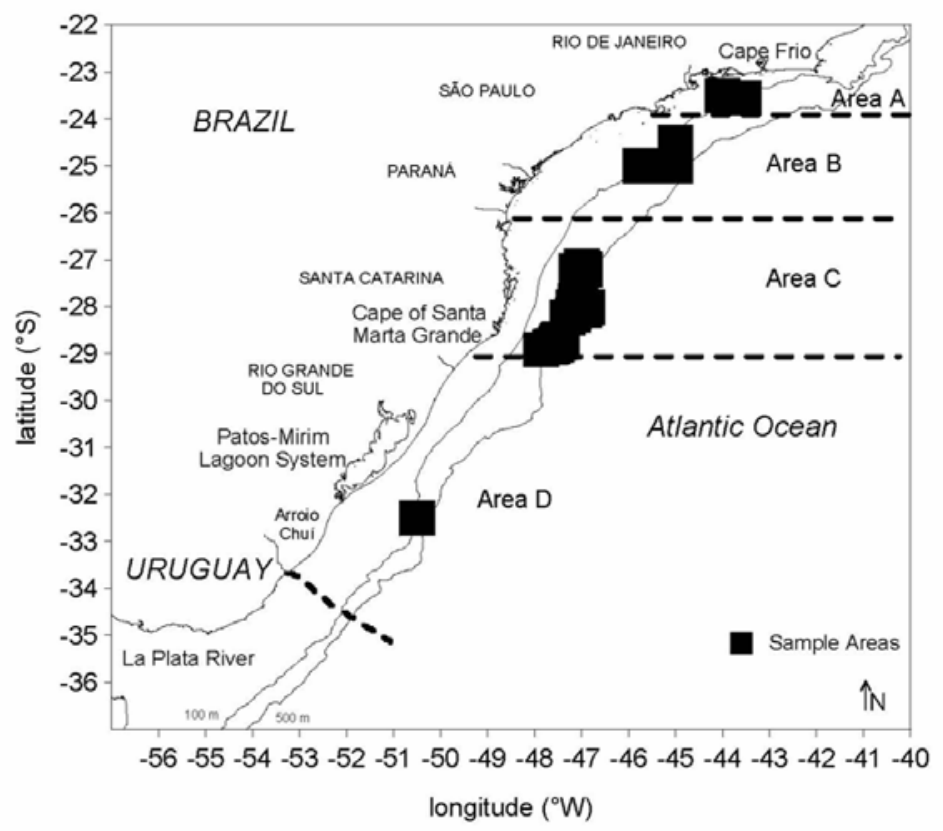

Fig. 1. Merluccius hubbsi: samples obtained from commercial bottom-trawls and surveys during summer and winter - 1996-2001 and 2004.

Spatial and temporal variations on the reproductive pattern were analyzed by two methods: frequency of different maturation stages and gonad indexes (VAZZOLER, 1996; KING, 2007). Considering areas $\mathrm{A}$ to $\mathrm{D}$, the frequency of maturation was analyzed, the spawning period being identified by the occurrence of a larger proportion of spawning and spent females. The frequency of $M$. hubbsi maturation stages in summer and winter were compared by a Kolmogorov-Smirnov test (ZAR, 1999; SIEGEL; CASTELLAN, 2006). Once those differences had been identified, this same test was applied for each season separately, the four areas being compared in accordance with the geographical gradient (areas A $\mathrm{x}$ $\mathrm{B}, \mathrm{B} \times \mathrm{C}$ and $\mathrm{C} \times \mathrm{D}$ ). Analyses were also conducted to determine the gonad index (GI) and gonadosomatic index (GSI) values, both calculated for the fish of each distinct area, season and stage of ovarian maturation (VAZZOLER, 1996), by the application of the following equations:

$\mathrm{GI}=\mathrm{Wo}_{\mathrm{o}} / \mathrm{LT}^{\mathrm{b}} \cdot 10^{6}$

$\mathrm{GSI}=(\mathrm{Wo} / \mathrm{WT}) \cdot 10^{2}$

where Wo is the ovarian weight, LT the total length, WT the total weight and "b" the coefficient of the length-weight relationship, fitted to a power model by the least square method (ZAR, 1999). GI and GSI values were plotted against total length and their correlations were analyzed (Spearman, after the D'Agostino Pearson normality test), independence and no relationship between the variables thus being ascertained, a prerequisite for the application of the indexes (BRAGA, 1986).

After data normality (D'Agostino Pearson) and homocedasticity (Bartlett) verifications, the values of the indexes were compared by season using a Mann-Whitney test. Since differences between seasons were stated, series data of GI and GSI for each season were compared by the Kruskal-Wallis test, taking the factor area into consideration (ZAR, 1999; SIEGEL; CASTELLAN, 2006). If differences were detected, a Student-Newman-Keuls (SNK) test was applied to the data. Comparisons of the indexes taking the ovarian maturation of $M$. hubbsi into consideration were not performed due to the unbalanced design and absence of the data relating to some categories, thus limiting the power of this analysis.

All the statistical analyses took Zar (1999) and Siegel and Castellan (2006) into account, and were carried out with the software Minitab $15^{\circledR}$ (licensed to the Universidade de São Paulo) and BioEstat 4.0 (free software, AYRES et al., 2005). The significance level adopted was $5 \%$. 


\section{Results}

The length frequency distribution of the 533 females $(164.00 \mathrm{~mm}<\mathrm{LT}<618.00 \mathrm{~mm})$ analyzed for each area and season is shown in Figure 2. The statistical description of the data is presented in Table 1 , as are the results of the normality test and of the application of Gulland's estimate of the minimum sample size, which was sufficient in all cases in view of the variability of the data, even in the winter in area $\mathrm{C}$, where the value obtained was lower than the estimated value. In Area D, due to its low abundance during summer, Merluccius hubbsi is not fished as a target by the commercial fleet, so few specimens were obtained from that area in that period.

Area A

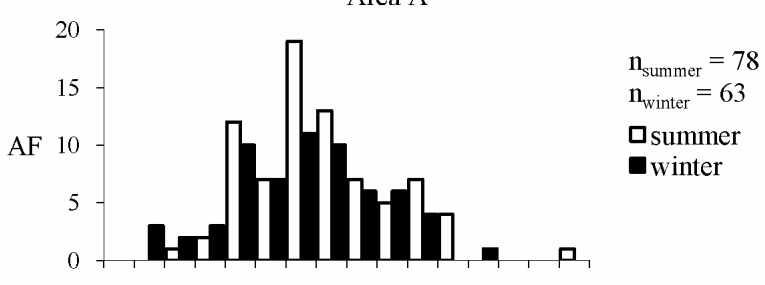

Area B
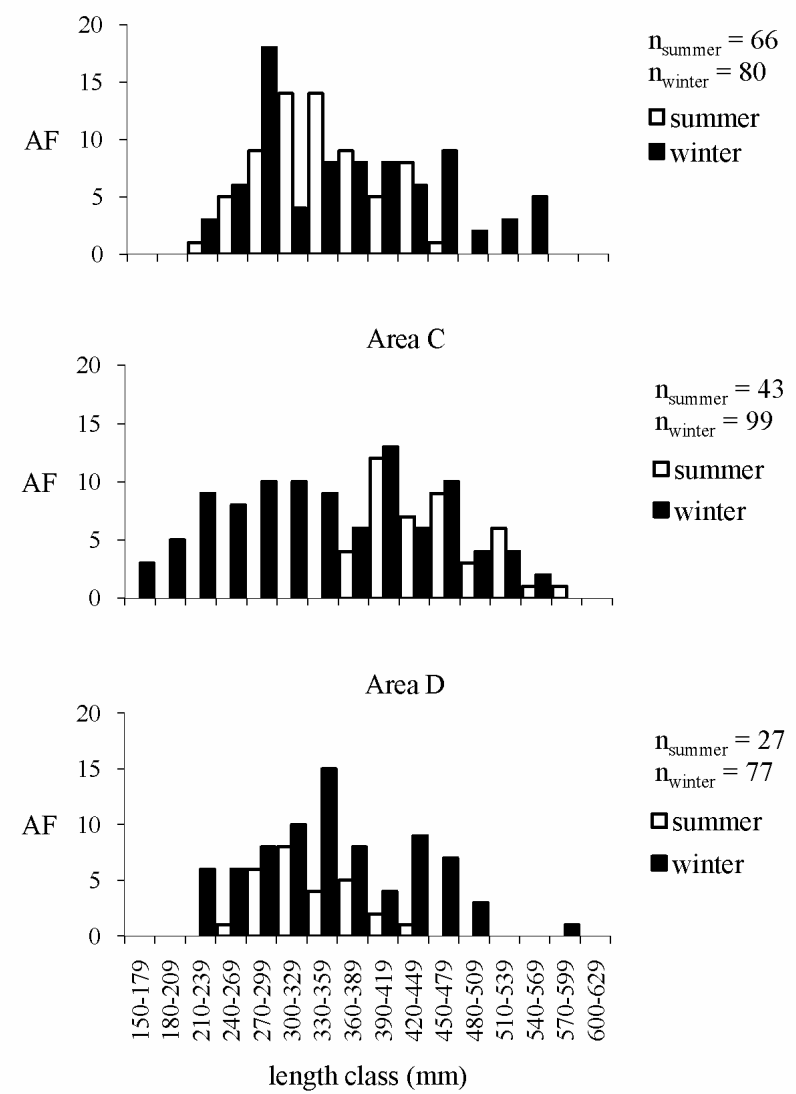

Fig. 2. Merluccius hubbsi: number of females (AF - absolute frequency) by class of total length (mm), by area (A to D), and season. 
Table 1. Merluccius hubbsi: statistical description of the total length, results of the D'Agostino Pearson normality test and number of fish enough ("n calculated") to ensure an adequate statistical sample size (* not normal).

\begin{tabular}{|c|c|c|c|c|c|c|c|c|c|c|c|}
\hline Season & Area & $\begin{array}{c}\mathrm{n} \\
\text { sampled }\end{array}$ & $\begin{array}{l}\text { Mean } \\
(\mathrm{mm})\end{array}$ & $\begin{array}{l}\text { Standard } \\
\text { deviation } \\
(\mathrm{mm})\end{array}$ & $\begin{array}{l}\text { Median } \\
(\mathrm{mm})\end{array}$ & $\begin{array}{l}\text { Minimum } \\
(\mathrm{mm})\end{array}$ & $\begin{array}{l}\text { Maximum } \\
(\mathrm{mm})\end{array}$ & Skewness & Kurtosis & $\begin{array}{l}\text { Normality Test } \\
\quad(p \text { value })\end{array}$ & $\begin{array}{c}\text { n calculated } \\
\text { (Gulland, } \\
1966)\end{array}$ \\
\hline \multirow{5}{*}{ Summer } & A & 78 & 365.36 & 68.88 & 352.50 & 221.00 & 618.00 & 0.72 & 1.21 & $0.009^{*}$ & 56 \\
\hline & B & 66 & 343.00 & 54.40 & 345.00 & 237.00 & 458.00 & 0.30 & -0.66 & 0.278 & 40 \\
\hline & $\mathrm{C}$ & 43 & 451.53 & 51.07 & 448.00 & 368.00 & 578.00 & 0.53 & -0.37 & 0.188 & 22 \\
\hline & $\mathrm{D}$ & 27 & 331.89 & 42.37 & 321.00 & 264.00 & 430.00 & 0.57 & -0.26 & 0.253 & 27 \\
\hline & Total & 214 & 371.56 & 71.48 & 362.50 & 221.00 & 618.00 & 0.53 & 0.03 & 0.124 & 58 \\
\hline \multirow{5}{*}{ Winter } & A & 63 & 346.19 & 73.46 & 347.00 & 189.00 & 517.00 & -0.09 & -0.41 & 0.665 & 72 \\
\hline & B & 80 & 370.70 & 83.30 & 363.50 & 230.00 & 558.00 & 0.38 & -0.96 & 0.106 & 79 \\
\hline & $\mathrm{C}$ & 99 & 348.00 & 91.60 & 350.00 & 164.00 & 568.00 & 0.11 & -0.89 & 0.237 & 109 \\
\hline & $\mathrm{D}$ & 77 & 352.82 & 80.00 & 345.00 & 214.00 & 585.00 & 0.28 & -0.27 & 0.469 & 81 \\
\hline & Total & 319 & 354.51 & 89.55 & 350.00 & 164.00 & 585.00 & 0.21 & -0.59 & 0.122 & 100 \\
\hline Total & & 533 & 361.35 & 83.12 & 355.00 & 164.00 & 618.00 & 0.23 & -0.33 & 0.217 & 83 \\
\hline
\end{tabular}

The female percentages by ovarian maturation stage in summer are presented in Figure 3 and the sum of spawning and spent for Areas A, B and C, 30.77\%, $15.15 \%$ and $20.93 \%$, respectively, indicated the presence of spawning females in that area and period, predominantly in Area A. No summer spawning activity was detected in Area D, where the females were immature, maturing or mature and only one was spawning. On the other hand, during winter (Fig. 4), spawning and spent females predominated in Area D $(22.08 \%)$, being followed by Area C $(20.20 \%)$ and Area B (7.50\%). No spawning females were detected in Area A, where only $6.35 \%$ of females were spent.

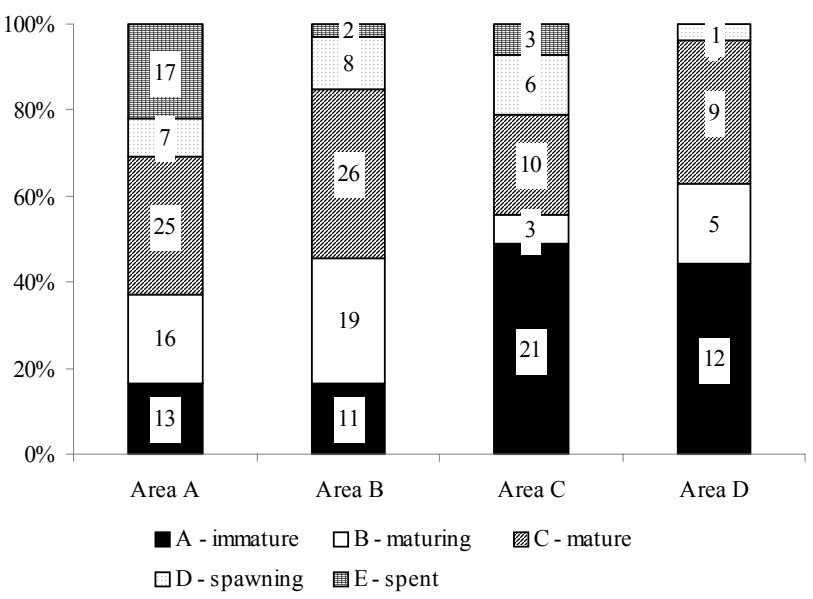

Fig. 3. Merluccius hubbsi: relative frequency of females by gonadal maturation stage by area during summer - 1996-2001 and 2004. 


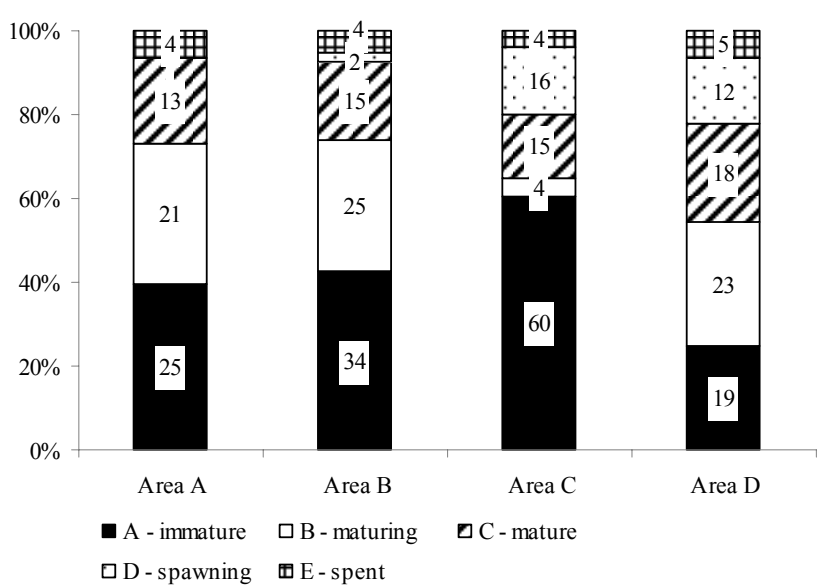

Fig. 4. Merluccius hubbsi: relative frequency of females gonadal maturation stage by area during winter - 1996-2001 and 2004.

The female frequencies in the distinct maturation stages during summer and winter were significantly different $\left(\mathrm{X}_{\mathrm{KS}}^{2}=19.31 ; \mathrm{p}<0.01\right)$. The comparison among areas is presented in Table 2 by season, showing that, during summer, Areas $\mathrm{A}$ and $\mathrm{B}$ were similar while areas $\mathrm{C}$ and $\mathrm{D}$ together formed another group. On the other hand, in winter, Areas A, $\mathrm{B}$ and $\mathrm{C}$ were homogeneous and Area $\mathrm{D}$ was markedly different from the other three.

Table 2. Merluccius hubbsi: statistics and p value of the Kolmogorov-Smirnov test applied to frequency of maturation (OK) females in areas A to D, in summer and winter.

\begin{tabular}{cccc}
\hline \hline Areas & Statistic & Summer & Winter \\
\hline A x B & $\mathrm{X}^{2}{ }_{\mathrm{KS}}$ & 5.04 & 1.89 \\
& $\mathrm{p}$ value & 0.1614 & 0.1112 \\
& & & \\
$\mathrm{~B} \times \mathrm{C}$ & $\mathrm{X}_{\mathrm{KS}}^{2}$ & 10.78 & 5.80 \\
& $\mathrm{p}$ value & 0.0092 & 0.1100 \\
$\mathrm{C} \times \mathrm{D}$ & $\mathrm{X}^{2}{ }_{\mathrm{KS}}$ & 1.97 & 22.37 \\
& $\mathrm{p}$ value & 0.7474 & $<0.001$ \\
\hline
\end{tabular}

Prior to the analysis of the indexes, the length-weight relationship was $\mathrm{Wt}=0.000004 \mathrm{Lt}^{3.094}$ $\left(\mathrm{n}=533 ; \mathrm{r}^{2}=0.974 ; \mathrm{p}<000.1\right)$.

There was no correlation between the fishes total length, the gonad index $\left(\mathrm{r}_{\mathrm{S}}=0.4676 ; \mathrm{p}>0.10\right)$ (Fig. 5) and the gonadosomatic index $\left(r_{S}=0.5436 ; p>\right.$ $0.10)$ (Fig. 6), allowing the use of these indexes to infer the reproductive phase of $M$. hubbsi.
The gonad index (GI) and the gonadosomatic index (GSI) values obtained for summer and winter differed significantly $(\mathrm{Z}(\mathrm{U})=$ 7.6609; $\mathrm{p}<0.001$ for $\mathrm{GI}$ and $\mathrm{Z}(\mathrm{U})=7.7272 ; \mathrm{p}<0.001$ for GSI). Thus, the analyses were conducted for summer and winter separately.

In summer, the median values of GI were 0.1454 for Area A, 0.0977 for Area B, 0.0596 for Area $\mathrm{C}$ and 0.04918 for Area D (Fig. 7a). The KruskalWallis test revealed differences among the values of these series $(\mathrm{KW}=20.3529 ; \mathrm{p}=0.0001)$; the SNK test showed that Areas A and B were similar $(\mathrm{p}=0.0911)$ but different from Areas C and D $(p=0.0722)$. Special attention must be drawn to the increasing difference between Area A, Area C ( $p=0.0073)$ and Area D $(p<$ 0.0001 ). On the other hand, the median GI values for winter were $0.04459,0.03960,0.0360$ and 0.0464 for Areas A to D, respectively (Fig. 7b), these values not being significantly different $(\mathrm{KW}=4.1176 ; \mathrm{p}=$ 0.2490).

The median gonadosomatic index (GSI) values were 3.495 (Area A), 2.436 (Area B), 1.564 (Area C) and 1.143 (Area D) in summer and 1.063 (Area A), 0.980 (Area B), 0.877 (Area C) and 1.118 (Area D) in winter (Fig. 8). In this case, only in summer did the Kruskal-Wallis test also reveal significant differences among the areas $(\mathrm{KW}=$ 20.5102; $p=0.0001)$. The SNK test indicated two similar areas, A x B and B x C ( $\mathrm{p}$ values $>0.05)$. The GSI values of Area $D$ were different from those for the other three areas, the smallest difference being observed in the contrast with Area $C(p=0.0344)$ and increasing northward in comparison with Areas B ( $p=$ $0.0027)$ and $A(p<0.0001)$. In winter, there was no difference among the values of GSI $(\mathrm{KW}=6.0086$; $p$ $=0.1112$ ). 


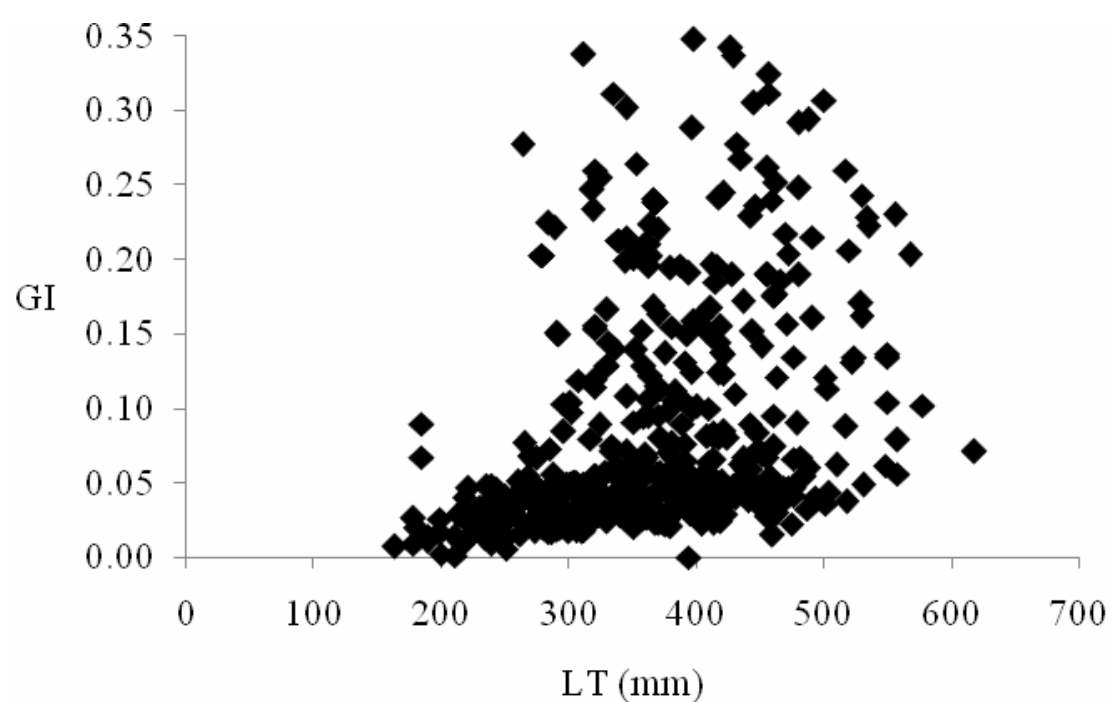

Fig. 5. Merluccius hubbsi: values of gonad index (GI) plotted against total length (LT).

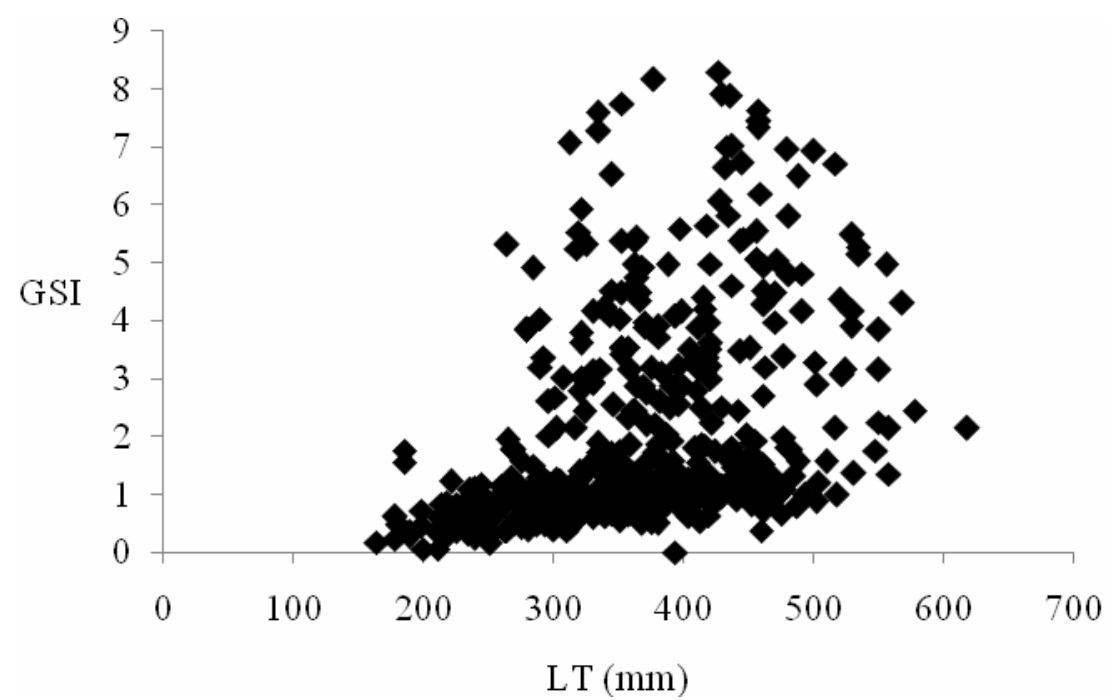

Fig. 6. Merluccius hubbsi: values of gonadosomatic index (GSI) plotted against total length (LT). 
A

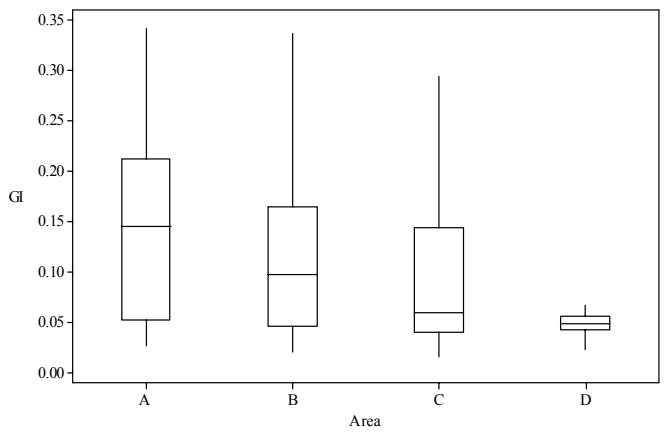

B

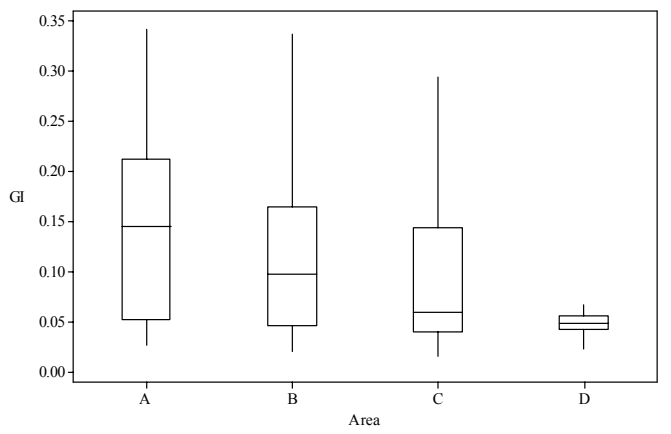

Fig. 7. Merluccius hubbsi: median, $1^{\text {st }}$ and $3^{\text {rd }}$ quartiles, minimum and maximum values of gonad index (GI) for areas A, B, C and D during summer (a) and winter (b) - 1996-2001 and 2004.

A

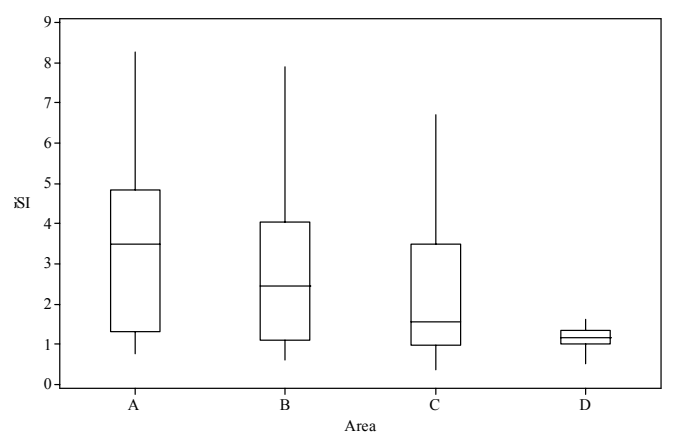

B

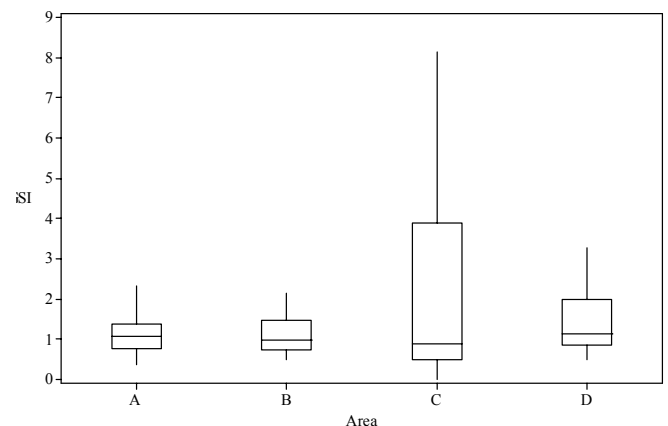

Fig. 8. Merluccius hubbsi: median, $1^{\text {st }}$ and $3^{\text {rd }}$ quartiles, minimum and maximum values of gonadosomatic index (GSI) for areas A, B, C and D during summer (a) and winter (b) - 1996-2001 and 2004.

\section{Discussion}

Life history characteristics, especially reproduction, are appropriate for the differentiation of stocks, because each group has its own attributes (SWAIN et al., 2005), even though with some measure of discreteness in terms of space and/or time (WALDMAN, 2005). The identification of the temporal and spatial extension of spawning is one of the most important factors for the definition of discrete stock units (BEGG et al., 1999b; BEGG, 2005). On the other hand, the knowledge of the variability among spawning groups gives support to the fishery sciences and general management (WALTERS; MARTELL, 2004; MUNRO et al., 2004; PAYNE et al., 2004; SECOR, 2007).

The Argentine hake's reproductive biology in Uruguayan and Argentinian waters is well known. Angelescu et al. (1958) were the pioneers in the study of the species' reproduction pattern and they were followed by Ciechomski (1967) with her analysis of its spawning and fecundity and Christiansen's (1971) and Christiansen and Cousseau's (1971) descriptions of its gonadal maturation. Many studies have been undertaken since then, including those conducted by Christiansen et al. (1986), Grunwaldt (1986), Simonazzi and Otero (1986), Olivieri and Christiansen (1987), Ubal et al. (1987), Louge and Christiansen (1992, 1993), Di Giácomo and Perier (1992), Bezzi and Dato (1993), Ehrlich and Ciechomski (1994), Portela et al. (1994), Louge (1996), Ruiz and Fondacaro (1997), Cornejo (1998), Bezzi and Tringali (2003), Sabatini (2004), Macchi et al. (2004), Pájaro et al. (2005) and Macchi et al. (2006). Di Giácomo et al. (1993) distinguished the Patagonian stock of $M$. hubbsi from neighboring groups by the species' spawning time and area. Nowadays, in Uruguay and Argentina, three stocks are recognized: one between 
$34^{\circ} \mathrm{S}-41^{\circ} \mathrm{S}$ (called "Bonaerense"), including the Argentinian-Uruguayan Common Fishing Zone (AUCFZ), another south of $41^{\circ} \mathrm{S}$ (Patagonian) and a third, restricted to the coastal area of the San Matías Gulf (AUBONE et al., 2000; BEZZI et al., 2004).

In Brazilian waters, all studies dealing with M. hubbsi's reproduction have been conducted with samples collected throughout the species' area of occurrence (Cape Frio, $21^{\circ} \mathrm{S}$, to Chuí, $34^{\circ} \mathrm{S}$ ). Vaz-dosSantos et al. (2005) estimated its first gonadal maturation and Honji et al. (2006) investigated its ovarian development. Vaz-dos-Santos and RossiWongtschowski (2005) confirmed that spawning occurs all year round in the Brazilian South-Southeast region, but called attention to the presence of more than one stock in the area and emphasized the need for a detailed analysis of $M$. hubbsi 's reproduction during summer and winter.

Olivieri and Christiansen's (1987) analysis shows that $M$. hubbsi's ovarian maturation is continuous over seven months and that multiple spawning occurs over an interval of four months. Ciechomski (1967) pointed out that the number of spawning and spent females may contribute to the analysis of spawning periods, since the percentages involved in those periods are noteworthy. In Brazil, the spawning and spent female frequencies indicate more intense spawning activity during summer in Area $\mathrm{A}$ and in winter in Area D, with areas B and C presenting a north-south spawning gradient, this affirmation being supported by statistical analysis that has shown the existence of two different groups in both seasons.

Gonad and gonadosomatic indexes reinforced the results obtained by the ovarian maturation analysis, being useful tools for the demonstration of the differentiation of $M$. hubbsi's Brazilian stock. Both these indexes were calculated to provide referential value comparisons with those of other studies and the information they provide does not differ as regards $M$. hubbsi's reproductive cycle. But the gonadosomatic index, a percentage, is more suitable, and may be recommended for future studies. The values of these indexes indicated ovarian weight variations as a consequence of oocyte maturation and their statistical analysis clarified the similarities and differences of this process throughout the area. In order to identify $M$. hubbsi's spawning season in the Southern Brazilian area (corresponding to area D of the present study), Haimovici et al. (1993) used the gonadosomatic and condition factor indexes, but a trustworthy analysis was also obtained from the gonadal maturation examination, showing that, in accordance with the results obtained, spawning occurs between August and October.

The use of reproductive indexes is not frequent in Uruguayan and Argentinian studies of $M$. hubbsi's reproductive cycle. Ciechomski (1967) found no relationship between the condition factor and fecundity, a fact attributed to the variability of values caused by its multiple spawning. Similar results were presented by Christiansen and Cousseau (1971), who analyzed data on M. hubbsi's "Bonaerense" and Patagonian stocks. Nevertheless, recently, Pájaro et al. (2005) applied the gonadosomatic index in an attempt to identify the spawning peak within a spawning period, and obtained consistent results. These results show that reproductive indexes may be helpful in detailing variations within a reproductive period in a specific area, being a tool for the detection of $M$. hubbsi's spawning peaks. This conclusion depends on the consideration that gonad indexes are good indicators of reproductive events, which reflect weight variations caused by the number and size of the oocytes (SWAIN et al., 2005). Pájaro et al.'s (2005) proposition finds support in the results obtained here, in which index values differ significantly within the area studied.

With regard to the Argentinian-Uruguayan Common Fishing Zone (AUCFZ), Ehrlich and Ciechomski (1986) reported M. hubbsi's winter spawning as taking place from May to August. Ubal et al. (1987) identified spawning during autumn, between $35^{\circ}-36^{\circ} \mathrm{S}$. In the Argentinian sea, Christiansen et al. (1986) found peculiar structures in histological portions of the gonads and muscles of $M$. hubbsi from different geographical areas and concluded that there are different stocks with distinct spawning periods in that area. According to these authors, spawning starts in Uruguay during autumn (first peak) and ends in Patagonian waters in spring-summer (second peak), extending southwards along a north-south gradient. Grunwaldt (1986) also identified different spawning periods, based on fecundity analysis. This reproductive pattern of $M$. hubbsi in Argentinian waters found support in Villarino and Giussi's (1992) study. This data set was reviewed by Louge and Christiansen (1993), Bezzi and Dato (1993) and Ehrlich and Ciechomski (1994), and corroborated by Bezzi et al. (1994), proving that one Argentinian hake stock spawns in winter, between $35^{\circ} \mathrm{S}$ and $38^{\circ} \mathrm{S}$, and another between $43^{\circ} \mathrm{S}$ and $47^{\circ} \mathrm{S}$, mainly in spring-summer. Ehrlich (2000) reinforces the north-south reproductive gradient pattern based on egg and larval distributions. The spawning phenomena of Argentine hake is associated with cold waters, with temperatures ranging f rom $9^{\circ} \mathrm{C}$ to $18^{\circ} \mathrm{C}$ (CIECHOMSKI; WEISS, 1973; LOUGE, 1996), the optimum being $9.4^{\circ} \mathrm{C}-13.3^{\circ} \mathrm{C}$ (BEZZI et al., 2004), recalling that the species is eurithermic, inhabiting waters with temperatures between $7^{\circ} \mathrm{C}$ and $23^{\circ} \mathrm{C}$ (PRENSKI; BEZZI, 1991; EHRLICH; CIECHOMSKI, 1994). 
The oceanographic characteristics of the Uruguayan and Argentinian sea, a portion of the South-Southeast America Large Marine Ecosystem (SSALME) (BISBAL, 1995), give support to its division into the "Bonaerense" and Patagonian sectors (PIOLA; RIVAS, 1997), due to the flow of the Malvinas (Falkland) Current and its mixing with coastal waters (GUERRERO; PIOLA, 1997). Torres et al. (1996) also found this association by analyzing juvenile otoliths and thus reinforced the stock segregation of $M$. hubbsi in the ArgentinianUruguayan Common Fishing Zone.

The results obtained in this study for the Argentine hake in Brazil in association with hydrographic information (sea temperature) available for the period of analysis (NOAA, 2005) allows us to give full weight to the evidence that the Southern Brazilian region (Area D) represents an extension of the "Bonaerense" M. hubbsi stock, whose spawning peak occurs in autumn-winter, when cold waters predominate. Others authors, such as Ciechomski and Weiss (1974), Torres-Pereira (1983, unpublished), Haimovici et al. (1993) and Torres et al. (1996) have previously presented this hypothesis, now confirmed as correct. The Santa Marta Grande Cape $\left(29^{\circ} \mathrm{S}\right)$, a region characterized by a narrow continental shelf with many upwellings (CASTRO et al., 2006), marks the northern limit of the "Bonaerense" stock, where cold waters derived from the Malvinas current mix with those from the La Plata River and the PatosMirim Lagoon System, giving rise to an environment with salinity around 33 and temperatures of $12^{\circ} \mathrm{C}$ $15^{\circ} \mathrm{C}$, mainly during winter (PIOLA et al., 1999). These features constitute an ecosystem which exercises great influence on many fish species living there, including M. hubbsi (HAIMOVICI et al., 1994; SEELIGER et al., 1998; VOOREN et al., 2005).

On the other hand, in the Southeastern region (Areas A, B and C, $21^{\circ} \mathrm{S}$ to $29^{\circ} \mathrm{S}$ ), M. hubbsi presents a spawning peak in spring-summer, related to the presence of the cold South Atlantic Central Water $\left(6^{\circ} \mathrm{C}<20^{\circ} \mathrm{C}, 34 \mathrm{~S}<36 \mathrm{~S}\right)$ (SILVEIRA et al., 2000; CASTRO et al., 2006). Upwelling phenomena are usual at $22^{\circ} 52^{\prime} \mathrm{S}$ (Cape Frio), extending to $23^{\circ} \mathrm{S}-25^{\circ} \mathrm{S}$ during summer (BRAGA; NIENCHESKI, 2006), influencing the life history of the $M$. hubbsi and other species that inhabit this area (ROSSIWONGTSCHOWSKI; PAES, 1993).

In relation to stocks, the Argentine hake should be managed in two distinct units: one in the Southeast (between $21^{\circ} \mathrm{S}$ and $29^{\circ} \mathrm{S}$, Areas A to C) and the other in the South (Area D, southward from $29^{\circ} \mathrm{S}$ ), both lying within the SSALME (BISBAL, 1995). The absence of juveniles of the species at $29^{\circ} \mathrm{S}$ (Santa Marta Grande Cape) (FIGUEIREDO et al., 2002; VAZ-DOS-SANTOS, 2002, unpublished) reinforces this division. According to Vaz-dos-Santos (op. cit.), juveniles concentrate in the Southeastern and Southern regions during spring-summer and autumn-winter, respectively, in agreement with the birth dates attributed to them from daily ring counts in otoliths (VAZ-DOS-SANTOS, 2006, unpublished ).

It is also important to consider the hypothesis of the existence of large latitudinal migrations of $M$. hubbsi as indicated by Angelescu et al. (1958) and stressed by Podestá (1990). These displacements have become better understood as a result of numerous studies conducted on the species' reproductive biology, which have shown that they are regional and related to smaller intra stock groups, as documented for other species (SECOR, 1999). Large displacements between $21^{\circ} \mathrm{S}$ and $34^{\circ} \mathrm{S}$ are, thus, improbable. Perez et al.'s (2003) data support this hypothesis, showing that the commercial fishing fleet operates all year round throughout the area of this study, though catches vary according to the season. Partial stock discreteness is usual, all round the world, for the genus Merluccius. Casey and Pereiro (1995), based on the reproductive life history and spatial distribution of juveniles, have demonstrated that there are two stocks of M. merluccius in the northeastern Atlantic and this has also been found for M. bilinearis on the Canadian and American Atlantic coasts (HESLER et al., 1995).

In the southeastern and southern Brazilian areas, there are other species with similar stock patterns (separation at $29^{\circ} \mathrm{S}$ and partial discreteness): Cynoscion guatucupa (HAIMOVICI;MIRANDA, 2005), Umbrina canosai (HAIMOVICI et al., 2006), Macrodon ancylodon (YAMAGUTI, 1979; CARNEIRO; CASTRO, 2005), Micropogonias furnieri (VAZZOLER, 1971; HAIMOVICI; IGNÁCIO, 2005) and Engraulis anchoita (CASTELLO, 2005). In the area south of $29^{\circ} \mathrm{S}$, these species are also shared, as is $M$. hubbsi, with Uruguay and Argentina and the recognition of this situation is an essential condition for their management (MUNRO et al., 2004; PAYNE et al., 2004). Regarding $M$. hubbsi, E. anchoita and U. canosai, Vaz-dos-Santos et al. (2006, unpublished) stressed the inconsistency and inefficiency of their present management, due to the fact that their shared stock status is not taken into consideration. These are only a few examples since there are at least forty commercial species shared among Brazil, Uruguay and Argentina (VAZ-DOSSANTOS et al., 2007), Vasconcellos and Haimovici (2006) being the only ones who have presented suggestions for the management of the shared stock of M. furnieri.

The overexploitation of M. hubbsi has been affirmed by Aubone et al. (2000, 2004) and Bezzi et al. (2004) for Uruguayan-Argentinian stocks, where the species has been managed. Overexploitation has only recently been detected in 
Brazil, by Vaz-dos-Santos and Rossi-Wongtschowski (2005), Vaz-dos-Santos et al. (2006), Perez and Pezzutto (2006), Vaz-dos-Santos (2006, unpublished) and Vaz-dos-Santos and Rossi-Wongtschowski (2007), but so far no regulation of hake fisheries has come into force. Considering the discreteness of the stocks and the fact that the South stock is shared with Uruguay and Argentina, the appropriate management of the species is urgently necessary.

\section{ACKNOWLEDGEMENTS}

The authors wish to thank Sra. Helcy Lilian Nogueira Silbiger for her preparation of the permanent histological cross-sections at the Laboratório de Ecologia Reprodutiva e do Recrutamento de Organismos Marinhos of the Instituto Oceanográfico of the Universidade de São Paulo (IOUSP). The first author is grateful to Drs. Naércio Aquino Menezes, Francisco Manoel de Souza Braga and Antônio Olinto Ávila-da-Silva for their helpful comments during the presentation of his D.Sc. thesis. Special thanks are due to Dr. June Ferraz Dias for her assistance. The librarians Mrs. Guillermina Cosulich and Mrs. Gabriela Silvoni have made access to many references possible, as also has scientific researcher Susana I. Bezzi, all of them of the Instituto Nacional de Investigación y Desarrollo Pesquero (INIDEP).

\section{REFERENCES}

ALHEIT, J.; PITCHER, T. J. Hake: fisheries, ecology and markets. London: Chapman \& Hall, 1995. 487 p.

ANGELESCU, V.; GNERI, F. S.; NANI, A. La merluza del Mar Argentino: biología y taxonomía. Buenos Aires: Servicio de Hidrografía Naval, 1958. 225 p.

AUBONE, A. et al. Merluza (Merluccius hubbsi). In: BEZZI, S. I.; AKSELMAN, R.; BOSCHI, E. E. (Ed.). Síntesis del estado de las pesquerías marítimas argentinas y de la Cuenca del Plata. Años 1997 - 1998, con la actualización de 1999. Mar del Plata: INIDEP, 2000. p. 30-39.

AUBONE, A. et al. Evaluación y sugerencias de manejo del recurso merluza (Merluccius hubbsi). La situación hasta 1999. In: SÁNCHEZ, R.; BEZZI, S. I. (Ed.). EI Mar Argentino y sus recursos pesqueros. Tomo 4: Los peces marinos de interés pesquero. Caracterización biológica y evaluación del estado de explotación. Mar del Plata: INIDEP, 2004. p. 207-235.

AYRES, M. et al. BioEstat: aplicações estatísticas na área das ciências biomédicas. Belém: Edição dos Autores, 2005. $324 \mathrm{p}$

BEGG, G. A. Life history parameters. In: CADRIN, S. X. FRIEDLAND, K. D.; WALDMAN, J. R. (Ed.). Stock identification methods: applications in fishery science. Oxford: Elsevier Academic Press, 2005. p. 119-150.
BEGG, G. A.; WALDMAN, J. R. A holistic approach to fish stock identification. Fish. Res., v. 43, p. 35-44, 1999.

BEGG, G. A.; FRIEDLAND, K. D.; PEARCE, J. B. Stock identification and its role in stock assessment and fisheries management: an overview. Fish. Res.,v. 43, p. $1-8,1999$ a.

BEGG, G. A.; HARE, J. A.; SHEEHAN, D. D. The role of life history parameters as indicators of stock structure. Fis. Res., v. 43, p. 141-163, 1999 b.

BELlisio, N. B. et al. Merluza. Buenos Aires: Ministerio da Economia/Secretaria de Estado de Intereses Marítimos/Subsecretaria de Pesca, 1978. 95 p.

BEVERTON, R. J. H.; HOLT, S. J. On the dynamics of exploited fish populations. London: Chapman \& Hall, $1993.538 \mathrm{p}$.

BEZZI, S. I.; DATO, C. Distribución estacional de los juveniles de merluza (Merluccius hubbsi) en la Zona Común de Pesca. Período Otoño 1986 - Verano 1987. Fr. Mar., v. 14, p.7-22, 1993.

BEZZI, S. I.; PERROTTA, R. G. Determinación de la unidad del stock de la merluza (Merluccius hubbsi) del mar argentino a través del análisis de los caracteres merísticos y morfométricos. Contr. INIDEP, v. 429, p. 1-28, 1983. BEZZI, S. I.; TRINGALI, L. Áreas de reproducción y de crianza de la merluza (Merluccius hubbsi): antecedentes científicos y relación con su marco regulatorio en la Republica Argentina. Fr. Mar., v. 19, p. $57-73,2003$.

BEZZI, S. I. et al. Report of the INIDEP working group on assessment of hake (Merluccius hubbsi) North of $48^{\circ} \mathrm{S}$ (Southwest Atlantic Ocean). INIDEP Doc. Cient., v. 3, p. 5-28, 1994.

BEZZI, S. I. et al. Caracterización biológica y pesquera de la merluza (Merluccius hubbsi). In: SÁNCHEZ, R.; BEZZI, S. I. (Ed.). EI Mar Argentino y sus recursos pesqueros. Tomo 4: Los peces marinos de interés pesquero. Caracterizacion biologica y evaluacion del Estado de explotación. Mar del Plata: INIDEP, 2004.

BISBAL, G. A. The Southeast South America Large Marine Ecosystem: evolution and components. Mar. Policy, v. 19, n. 1, p. 21-38, 1995.

BRAGA, F. M. S. Estudo entre fator de condição e relação peso/comprimento para alguns peixes marinhos. Rev. Bras. Biol., v. 46, n. 2, p. 339-346. 1986.

BRAGA, E. S.; NIENCHESKI. L. F. H. Composição das massas de água e seus potenciais produtivos na área entre o Cabo de São Tomé (RJ) e o Chuí (RS). In: ROSSIWONGTSCHOWSKI, C. L. D. B.; MADUREIRA, L. S. P. (Ed.). O ambiente oceanográfico da Plataforma Continental e do Talude na Região Sudeste-Sul do Brasil. São Paulo: Edusp, 2006. p. 161-218.

CADRIN, S. X.; FRIEDLAND, K. D.; WALDMAN, J. R. Stock identification methods - an overview. In: CADRIN, S. X.; FRIEDLAND, K. D.; WALDMAN, J. R. Stock identification methods: applications in fishery science. Oxford: Elsevier Academic Press, 2005a. p.3-6.

CADRIN, S. X.; FRIEDLAND, K. D.; WALDMAN, J. R. Stock identification methods: applications in fishery science. Oxford: Elsevier Academic Press, 2005b. 719p.

CARNEIRO, M. H.; CASTRO, P. M. G. Macrodon ancylodon (Bloch \& Schneider, 1801). In: CERGOLE, M. C.; ÁVILA-DA-SILVA, A. O.; ROSSIWONGTSCHOWSKI, C. L. D. B. (eds.). Análise das principais pescarias comerciais da Região Sudeste-Sul 
do Brasil: dinâmica populacional das espécies em explotação. São Paulo: IOUSP / Série Documentos REVIZEE, 2005. p.81-87.

CASEY, J.; PEREIRO, J. European hake (M. merluccius) in the North-east Atlantic. In: ALHEIT, J.; PITCHER, T. J. Hake: fisheries, ecology and markets. London: Chapman \& Hall, 1995. p. 125-147.

CASTELLO, J. P. Engraulis anchoita (Hubbs \& Marini, 1935). In: CERGOLE, M. C.; ÁVILA-DA-SILVA, A O.; ROSSI-WONGTSCHOWSKI, C. L. D. B. (Ed.) Análise das principais pescarias comerciais da Região Sudeste-Sul do Brasil: dinâmica populacional das espécies em explotação. São Paulo: IOUSP / Série Documentos REVIZEE, 2005. p. 52-56.

CASTRO, B. M. et al. Estrutura termohalina e circulação na região entre o Cabo de São Tomé (RJ) e o Chuí (RS). In: ROSSI-WONGTSCHOWSKI, C. L. D. B MADUREIRA, L. S. P. (Ed.). O ambiente oceanográfico da Plataforma Continental e do Talude na Região Sudeste-Sul do Brasil. São Paulo: Edusp, 2006. p. 11-120.

CHRISTIANSEN, H. E. Descripción histológica del ciclo del ovario de merluza. Boln Inst. Biol. mar., v. 20, p. 3-41, 1971.

CHRISTIANSEN, H. E.; COUSSEAU, M. B. La reproducción de la merluza y su relación con otros aspectos biológicos de la especie. Boln Inst. Biol. mar., v. 20, p. $43-75,1971$

CHRISTIANSEN, H. E.; GLORIOSO, P. D.; OLIVIERI, C. E. Aplicación de la histología en la determinación de los efectivos de merluza (Merluccius hubbsi). Tipificación de tejidos, cálculos de la fecundidad y vinculación con las condiciones ambientales. Publ. Com. Téc. Mix. Fr. Mar., v. 1, n. 2, p.567-574, 1986.

CIECHOMSKI, J. D. Carácter del desove y fecundidad de la merluza argentina Merluccius hubbsi del sector bonaerense. Boln Inst. Biol. mar., v. 13, p.1-15, 1967.

CIECHOMSKI, J. D.; WEISS, G. Nota sobre la presencia de huevos y larvas de la merluza Merluccius merluccius hubbsi, en el Mar Argentino. Physis, B. Aires, v. 32, n. 84, p.155-160, 1973

CIECHOMSKI, J. D.; WEISS, G. Distribución de huevos y larvas de merluza, Merluccius merluccius hubbsi, en las aguas de la plataforma de la Argentina y Uruguay en relación con la anchoíta, Engraulis anchoita, y las condiciones ambientales. Physis, B. Aires, v. 33, n. 86, p.185-198, 1974.

CORNEJO, A. M. Descripción histológica de las fases de los folículos post-ovulatorios en ovarios de merluza común (Merluccius hubbsi). Revta Biol. Mar. Oceanog., v. 33 n. 1, p.89-99, 1998.

COUSSEAU, M. B.; JOHN, H. C. Undesirable catches of small fish in Argentinean hake fisheries. Arch. Fisch. Wiss., v. 27, n. 1, p. 45-54, 1976.

COUSSEAU, M. B.; PERROTTA, R. G. Peces marinos de Argentina: biología, distribución, pesca. Mar del Plata: INIDEP, 2004. $167 \mathrm{p}$.

CSIRKE, J. Introducción a la dinámica de poblaciones de peces. FAO Doc. téc. Pesca, v. 192, p.1-82, 1980.

CSIRKE, J. The Patagonian(?OK) fishery resources and the offshore fisheries in the South-West Atlantic. FAO Fish. tech. Pap., v. 286, p.1-75, 1987
DI GIÁCOMO, E. E. et al. Spawning aggregations of Merluccius hubbsi, in Patagonian waters: evidence for a single stock? Fish. Res., v. 16, n. 1, p. 9-16, 1993.

DI GIÁCOMO, E. E.; PERIER, M. R. Abundancia, estructura poblacional y zona de desove de la merluza (Merluccius hubbsi) en el Golfo San Matías, Argentina. Fr. Mar., n. 12, p.47-52, 1992.

DI GIÁCOMO, E. E. et al. Spawning aggregations of Merluccius hubbsi, in Patagonian waters: evidence for a single stock? Fish. Res., v. 16, n. 1, p. 9-16, 1993.

EHRLICH, M. D. Distribución y abundancia de huevos, larvas y juveniles de merluza (Merluccius hubbsi) en la Zona Común de Pesca Argentino-Uruguaya, 1996-1998. Fr. Mar., v. 18, p. 31-44, 2000

EHRLICH, M. D.; CIECHOMSKI, J. D. Nuevos aportes sobre el desove invernal de merluza (Merluccius hubbsi) en aguas de la plataforma del Atlántico Sudoccidental entre las latitudes de $34^{\circ}$ y $36^{\circ} \mathrm{S}$. Publ. Com. Téc. Mix. Fr. Mar., v. 1, n. 2, p. 299-309, 1986

EHRLICH, M. D.; CIECHOMSKI, J. D. Reseña sobre la distribución de huevos y larvas de merluza (Merluccius hubbsi) basada en veinte años de investigaciones. Fr. Mar., v. 15, p. 37-50, 1994.

FAO. Código de Conducta para la Pesca Responsable. Roma: FAO, 1995. 46 p. FIGUEIREDO, J. L.; MENEZES, N. A. Manual de peixes marinhos do Sudeste do Brasil II: Teleostei (1). São Paulo: Museu de Zoologia da USP, $1978.90 \mathrm{p}$.

FIGUEIREDO, J. L. et al. Peixes da Zona Econômica Exclusiva do Brasil: levantamento com rede de meia água. São Paulo: Edusp ; REVIZEE ; Imprensa Oficial do Estado, 2002. 242 p.

GIUSSI, A. R.; VILLARINO, F.; DATO, C. Distribución geográfica por grupos de edad de la merluza (Merluccius hubbsi) en el Mar Argentino entre los $35^{\circ}-47^{\circ}$ LS en el año 1983. Fr. Mar., v. 15, p. 7-19, 1994.

GRUNWALDT, P. Contribución al conocimiento de la fecundidad y carácter del desove de la merluza (Merluccius hubbsi). Publ. Com. Mix. Téc. Fr. Mar., v. 1, n. 1, p. 66-74, 1986.

GUERRERO, R. A.; PIOLA, A. R. Masas de agua en la plataforma continental. In: BOSCHI, E. E. (Ed.). EI Mar Argentino y sus recursos pesqueros. Tomo 1: Antecedentes históricos de las explotaciones en el mar y las características ambientales. Mar del Plata: INIDEP, 1997. p. 107-118.

GULland, J. A. Manual de métodos de muestreo y estadisticos para la biología pesquera: Parte 1 . Métodos de Muestreo. Roma: FAO, 1966. 87 p.

GULLAND, J. A. Fish stock assessment: a manual of basic methods. New York: Wiley, 1983. 223 p.

GUTIÉRREZ, L. M; RUIZ, A. E.; SENDÍN, M. E. Identificación del stock de merluza (Merluccius hubbsi) en el área de Isla Escondida. Naturalia patagónica, Ciencias Biológicas, v. 3, p.11-23, 1995.

HAIMOVICI, M.; IGNÁCIO, J. M. Micropogonias furnieri (Desmarest, 1823). In: CERGOLE, M. C.; ÁVILA-DASILVA, A. O.; ROSSI-WONGTSCHOWSKI, C. L. D. B. (eds.). Análise das principais pescarias comerciais da Região Sudeste-Sul do Brasil: dinâmica populacional das espécies em explotação. São Paulo: IOUSP, 2005. p. 101-107. (Série Documentos REVIZEE). 
HAIMOVICI, M.; MIRANDA, L. V. Cynoscion guatucupa (Cuvier, 1830). In: CERGOLE, M. C.; ÁVILA-DASILVA, A. O.; ROSSI-WONGTSCHOWSKI, C. L. D. B. (eds.). Análise das principais pescarias comerciais da Região Sudeste-Sul do Brasil: dinâmica populacional das espécies explotação. São Paulo: IOUSP, 2005. p.40-45. (Série Documentos REVIZEE).

HAIMOVICI, M.; MARTINS, A. S.; TEIXEIRA, E. R. L. Distribución, alimentación y observaciones sobre la reproducción de la merluza (Merluccius hubbsi) en el Sur de Brasil. Fr. Mar., v. 14, p. 33-40, 1993.

HAIMOVICI, M. et al. Demersal bony fish of the outer shelf upper slope of the southern Brazil Subtropical Convergence Ecosystem. Mar.Ecol.Prog.Series, v. 108, p. 59-77, 1994.

HAIMOVICI, M. et al. Umbrina canosai Berg 1895. In: ROSSI-WONGTSCHOWSKI, C. L. D. B.; ÁVILA-DASILVA, A. O.; CERGOLE, M. C. (Ed.). Análise das principais pescarias comerciais da Região Sudeste-Sul do Brasil: dinâmica populacional das espécies em explotação - II. São Paulo: IOUSP, 2006. p. 77-85.(Série Documentos REVIZEE) .

HART, T. J. The distribution and biology of hake. Biol. Rev. Cambridge Phil. Soc., v. 23, n. 1, p. 62-80, 1948.

HESLER, T. E.; ALMEIDA, F. P.; WALDRON, D. E. Biology and fisheries of North-west Atlantic hake (silver hake: $M$. bilinearis). In: ALHEIT, J.; PITCHER, T. J. Hake: fisheries, ecology and markets. London: Chapman \& Hall, 1995. p.203-237.

HILBORN, R.; WALTERS, C. J. Quantitative fisheries stock assessment. London: Chapman \& Hall, 1992. 570 p.

HONJI, R. M.; VAZ-DOS-SANTOS, A. M.; ROSSIWONGTSCHOWSKI, C. L. D. B. Identification of the stages of ovarian maturation of the Argentine hake Merluccius hubbsi Marini, 1933 (Teleostei: Merlucciidae): advantages and disadvantages of the use of the macroscopic and microscopic scales. Neotrop. Ichthyol., v. 4, n. 3, p. 329-337, 2006.

KING, M. Fisheries biology, assessment and management 2 ed. Oxford: Blackwell Science, 2007. 382 p.

KRUSE, G. H. et al. Fisheries assessment and management in data-limited situations. Fairbanks: Alaska Sea Grant College Program / University of Alaska Fairbanks, 2005. 948 p.

LOUGE, E. B. Variaciones espacio-temporales del fenómeno reproductivo de la merluza Merluccius hubbsi Marini 1933 durante su concentración invernal en la Zona Común de Pesca Argentino-Uruguaya. Boln Inst. esp. Oceanog., v. 11, n. 2, p.123-139, 1996.

LOUGE, E. B.; CHRISTIANSEN, H. E. Dinámica reproductiva de la merluza Merluccius hubbsi Marini, 1933, durante su concentración estival de 1988 en la Costa de Argentina. Biol. Pesq., v. 21, p. 3-14, 1992.

LOUGE, E. B.; CHRISTIANSEN, H. E. Fecundidad de la merluza Merluccius hubbsi durante la temporada estival de 1988. Boln Inst. esp. Oceanogr., v. 9, n. 2, p.343346,1993

MACCHI, G. J.; PÁJARO, M.; EHRLICH, M. D. Seasonal egg production pattern of the Patagonian stock of Argentine hake (Merluccius hubbsi). Fish. Res., v. 67, n. 1, p. 25-38, 2004.
MACCHI, G. J. et al. Influence of size, age and maternal condition on the oocyte dry weight of Argentine hake (Merluccius hubbsi). Fish. Res., v. 80, p. 345-349, 2006.

MENEZES, N. A. et al. Catálogo das espécies de peixes marinhos do Brasil. São Paulo: Museu de Zoologia da USP, 2003. $160 \mathrm{p}$.

MMA. PROGRAMA REVIZEE: avaliação do potencial sustentável de recursos vivos da Zona Econômica Exclusiva do Brasil - relatório executivo. Brasília: MMA, 2006. 280 p.

MUNRO, G; A.; VAN HOUTTE, E.; WILLMANN, R. The conservation and management of shared fish stocks: legal and economic aspects. FAO Fish. tech. Pap., n. 465, p.1- 67, 2004.

NOAA. National Oceanic and Atmospheric AdministrationCIRES Climate Diagnostics Center: document maintained by Data Management Group (cdcdata@noaa.gov). Updated: Jan 19, 2005 16:11:54 MST.< http://www.cdc.noaa.gov/cgi-bin/GrADS.pl $>$.

OLIVIERI, C.; CHRISTIANSEN, H. E. Consideraciones preliminares sobre la frecuencia reproductiva de la merluza común (Merluccius hubbsi). Publ. Com. Téc Mix. Fr. Mar., v. 3, p. 67-71, 1987. OTERO, H. O. Abundancia relativa y rendimiento maximo sostenible de la merluza común (Merluccius hubbsi). Revista de Investigación y Desarrollo Pesquero, v. 2, n. 2, p. 1322,1980 .

OTERO, H. O. et al. Los recursos pesqueros demersales del Mar Argentino - parte II - distribución, estructura de la población, biomasa e rendimiento potencial de la merluza común. Contr. INIDEP, v. 383, p. 21-27, 1981.

PÁJARO, M.; MACCHI, G.; MARTOS, P. Reproductive pattern of the Patagonian stock of Argentine hake (Merluccius hubbsi). Fish. Res., n. 72, p. 97-108, 2005.

PAYNE, A. I. L.; O'BRIEN, C. M.; ROGERS, S. I. Management of shared fish stocks. Oxford: Blackwell Publishing, 2004. 367 p.

PEREZ, J. A. A. et al. Deep-sea fishery off Southern Brazil: recent trends of the Brazilian Fishing Industry. J. Northw. Atl. Fish. Sci., v. 31, p.1-18, 2003.

PEREZ, J. A. A.; PEZZUTTO, P. R. A pesca de arrasto de talude do Sudeste e Sul do Brasil: tendências da frota nacional entre 2001 e 2003. Bolm Inst. Pesca, S Paulo, v. 32 , n. 2 , p.127-150, 2006

PERROTTA, R. G.; SANCHÉZ, F. Una vez más acerca de la identificación de las poblaciones de merluza (Merluccius hubbsi) en la Plataforma Argentino-Uruguaya. Fr. Mar., v. 12, p.39-46, 1992.

PIOLA, A. R. et al. Continental shelf water masses off eastern South America $-20^{\circ}$ to $40^{\circ} \mathrm{S}$. Symposium On Global Change Studies, v. 10, p. '9-12, 1999.

PIOLA, A. R.; RIVAS, A. L. Corrientes en la plataforma continental. In: Boschi, E. E. (ed.). El Mar Argentino y sus recursos pesqueros. Tomo 1: Antecedentes históricos de las explotaciones en el mar y las características ambientales. Mar del Plata: INIDEP, 1997. p.119-132.

PODESTÁ, G. P. The relative fishing power of the Argentinian offshore fleet fishing for hake (Merluccius hubbsi) in 1978 and 1979. J. Cons. int. Explor. Mer., v. 43 , p. $268-271,1987$. 
PODESTÁ, G. P. Migratory pattern of Argentine hake Merluccius hubbsi and oceanic processes in the Southwestern Atlantic Ocean. Fish. Bull., v. 88, p. 167177, 1990.

PORTELA, J. M.; CONTRERAS, N. P.; GORBEA, V. T. Aspectos reproductivos del calamarete (Loligo gahi), el calamar (Illex argentinus) y la merluza (Merluccius hubbsi) en el Atlántico Sudoccidental. Publ. Com. Téc. Mix. Fr. Mar., v. 15, p. 21-36, 1994.

PRENSKI, L. B.; BEZZI, S. I. Interdependencia de la estructura de talla de la merluza (Merluccius hubbsi) y los factores abióticos y bióticos. Estimación cuantitativa del canibalismo en la Zona Común de Pesca ArgentinoUruguaya. Fr. Mar., v. 8, p. 7-28, 1991.

QUINN, T. J.; DERISO, R. B. Quantitative fish dynamics. Oxford: Oxford University Press, 1999. 542 p.

REY, M.; ARENA, G. Merluza (Merluccius hubbsi): estudios realizados dentro de la Zona Común de Pesca Argentino-Uruguaya en el marco del plan de investigación pesquera. Montevideo: INAPE/PNUD, 1999. $211 \mathrm{p}$

REY, M.; GRUNWALDT, P. Evaluación de la merluza (Merluccius hubbsi) en la Zona Común de Pesca Argentino-Uruguaya, verano 1982. Publ. Com. Téc. Mix. Fr. Mar., v. 1, n. 1, p.121-134, 1986

ROSSI-WONGTSCHOWSKI, C. L. D. B. PAES, E. T. Padrões espaciais e temporais da comunidade de peixes demersais do litoral norte do Estado de São Paulo Ubatuba, Brasil. Publção. esp. Inst. oceanogr., S Paulo, v. 10, p. 169-188, 1993.

RUIZ, A. E.; FONDACARO, R. R. Talla de primera madurez de merluza (Merluccius hubbsi) en el área de Isla Escondida, Patagonia (Diciembre 1989 - Enero 1994). Naturalia patagónica, Ciencias Biológicas, v. 5, p. 2938, 1997.

SABATINI, M. E. Características ambientales, reproducción y alimentación de la merluza (Merluccius hubbsi) y la anchoita (Engraulis anchoita) en su habitat reproductivo patagónico: síntesis y perspectivas. Revta Invest. Des. Pesq., v. 16, p.5-25, 2004.

SARDELLA, N. H.; TIMI, J. T. Parasites of Argentine hake in the Argentine Sea: population and infracommunity structure as evidence for host stock discrimination. J. Fish Biol., v. 65, p. 1472-1488, 2004.

SECOR, D. H. Specifying divergent migrations in the concept of stock: the contingent hypothesis. Fish. Res. v. 43, p. 13-34, 1999.

SECOR, D. H. The year-class phenomenon and the storage effect in marine fishes. J. Sea Res., v. 57, p. 91-103, 2007.

SEELIGER, U.; ODEBRECHT, C.; CASTELlO, J. P. Os ecossistemas costeiro e marinho do extremo sul do Brasil. Rio Grande: Ecoscientia, 1998. 326 p.

SIEGEL, S.; CASTELLAN, N. J. Estatística nãoparamétrica para ciências do comportamento. 2. ed. Porto Alegre: ARTMED, 2006. 448 p.

SILVEIRA, I. C. A. et al. Corrente do Brasil ao largo da costa leste brasileira. Braz. J. Oceanogr., v. 48, p.171 $183,2000$.

SIMONAZZI, M.; OTERO, H. O. Aspectos de la estructura de población de la merluza común (Merluccius hubbsi). I Largo y edad de primera madurez, relación largo-peso. Publ. Com. Téc. Mix. Fr. Mar., v. 1, n. 1, p.135-146, 1986.
SPARRE, P.; VENEMA, S. C. Introduction to tropical fish stock assessment. FAO Fish. tech. Pap., v. 306, n. 1, Rev. 2, p. 1-407, 1998.

SWAIN, D. P.; FOOTE, C. J. Stocks and chameleons: the use of phenotypic variation in stock identification. Fish. Res., v. 43, p. 113-128, 1999.

SWAIN, D. P.; HUTCHINGS, J. A.; FOOTE, C. J. Environmental and genetic influences on stock identification characters. In: CADRIN, S. X.; FRIEDLAND, K. D.; WALDMAN, J. R. (Ed.). Stock identification methods: applications in fishery science. Oxford: Elsevier Academic Press, 2005. p. 4585.

TORRES, G. J.; NORBIS, W.; LORENZO, M. I. Variations in the measures of Argentine hake (Merluccius hubbsi) rings otoliths during their first-year: evidence for stock separation? Sci. Mar., v. 60, n. 2-3, p. 331-338, 1996.

TRIOLA, M. F. Introdução à estatística. 9. ed. Rio de Janeiro: LTC, 2005. 656 p.

UBAL, W. et al. Estudio del stock desovante de la merluza (Merluccius hubbsi) en la Zona Común de Pesca Argentino-Uruguaya. Publ. Com. Téc. Mix. Fr. Mar., v. 3, p. 59-66, 1987. VALENTINI, H.; PEZZUTTO, P. R. Análise das principais pescarias comerciais da Região Sudeste/Sul do Brasil com base na produção controlada do período 1986 - 2004. São Paulo: IOUSP, 2006. 51 p. (Série Documentos REVIZEE).

VASCONCELLOS, M.; HAIMOVICI, M. Status of white croaker Micropogonias furnieri exploited in southern Brazil according to alternative hypotheses of stock discreetness. Fish. Res., v. 80, p. 196-202, 2006.

VAZ-DOS-SANTOS, A. M.; ROSSI-WONGTSCHOWSKI, C. L. D. B. Merluccius hubbsi Marini, 1933. In: CERGOLE, M. C.; ÁVILA-DA-SILVA, A. O.; ROSSIWONGTSCHOWSKI, C. L. D. B. (Ed.). Análise das principais pescarias comerciais da Região Sudeste-Sul do Brasil: dinâmica populacional das espécies em explotação. São Paulo: IOUSP, 2005. p. 88-93. (Série Documentos REVIZEE).

VAZ-DOS-SANTOS, A. M.; ROSSI-WONGTSCHOWSKI, C. L. D. B. Age and growth of the Argentine hake Merluccius hubbsi Marini, 1933 in the Brazilian SouthSoutheast Region during 1996-2001. Neotrop. Ichthyol., v. 5 , n. 3, p. $375-386,2007$

VAZ-DOS-SANTOS, A. M.; HONJI, R. M.; ROSSIWONGTSCHOWSKI, C. L. D. B. Comprimento e idade da primeira maturação gonadal de fêmeas de merluza Merluccius hubbsi Marini, 1933 na Região Sudeste-Sul do Brasil. Bolm Inst. Pesca, S Paulo, v. 31, n. 2, p.109117,2005

VAZ-DOS-SANTOS, A. M; ROSSI-WONGTSCHOWSKI, C. L. D. B.; FIGUEIREDO, J. L. Recursos pesqueiros compartilhados entre Brasil, Uruguai e Argentina: a problemática de Merluccius hubbsi, Engraulis anchoita, Umbrina canosai e Illex argentinus. In: SEMINÁRIO DE GESTÃO SOCIOAMBIENTAL PARA O DESENVOLVIMENTO SUSTENTÁVEL DA AQÜICULTURA E DA PESCA NO BRASIL, 2, 2006, Rio de Janeiro. Rio de Janeiro: COPPE/UFRJ, 2006. p.1-10.

VAZ-DOS-SANTOS, A. M.; ROSSI-WONGTSCHOWSKI, C. L. D. B.; FIGUEIREDO, J. L. Recursos pesqueiros compartilhados: bioecologia, manejo e aspectos 
aplicados no Brasil. Bolm Inst. Pesca, S Paulo, v. 33, n. 2, p. 273-292, 2007 .

VAZZOLER, A. E. A. DE M. Biologia da reprodução de peixes teleósteos: teoria e prática. Maringá: EDUEM, 1996. $169 \mathrm{p}$

VAZZOLER, A. E. A. de M. Diversificação morfológica e fisiológica de Micropogonias furnieri (Desmarest, 1823) ao sul de Cabo Frio, Brasil. Bolm. Inst. Oceanogr., S Paulo, v. 20, n. 2, p.1-70, 1971.

VILLARINO, F.; GIUSSI, A. Distribución geográfica por grupo de edad de la merluza común (Merluccius hubbsi) durante 1982 en el Mar Argentino entre los $35^{\circ}-47^{\circ} \mathrm{S}$. Boln Inst. esp. Oceanogr., v. 8, n. 2, p.339-353, 1992.

VOOREN, C. M. et al. A Plataforma Sul e os métodos de trabalho. In: VOOREN, C. M.; KLIPPEL, S. (Ed.). Ações para a conservação de tubarões e raias no Sul do Brasil. Porto Alegre: Igaré, 2005. p.13-22.

WALDMAN, J. R. Definition of stocks: an evolving concept. In: CADRIN, S. X.; FRIEDLAND, K. D.; WALDMAN, J. R. (Ed.). Stock identification methods: applications in fishery science. Oxford: Elsevier Academic Press, 2005. p.7-16.

WALTERS, C. J.; MARTELL, S. J. D. Fisheries ecology and management. Princeton: Princeton University Press, 2004. 399 p.

YAMAGUTI, N. Diferenciação geográfica de Macrodon ancylodon (Bloch \& Schneider, 1801) na costa brasileira, entre as latitudes $18^{\circ} 36^{\prime} \mathrm{S}$ e $32^{\circ} 10^{\prime} \mathrm{S}$, etapa 1 . Bolm. Inst. Oceanogr., S Paulo, v. 28, n. 1, p. 53-118, 1979.

ZAR, J. H. Biostatistical analysis. 4. ed. New Jersey: Prentice Hall, 1999. 663 p.
Sources of Unpublished Material

TORRES-PEREIRA, I. G. Morfometria, caracteres merísticos, osteologia e alimentação dos estágios larvais, e distribuição dos ovos e larvas de merluza, Merluccius hubbsi, (Gadiformes, Merlucciidae), na plataforma continental do Rio Grande do Sul. 1983. 105p. Dissertação (Mestrado em Oceanografia Biológica) - Fundação Universidade Federal do Rio Grande, Rio Grande, 1983.

VAZ-DOS-SANTOS, A. M. Idade e crescimento da merluza, Merluccius hubbsi Marini, 1933 (Teleostei: Merlucciidae) na Zona Econômica Exclusiva entre o Cabo de São Tomé (RJ) e o Chuí (RS), Brasil. 2002. 191 p. Dissertação (Mestrado em Oceanografia Biológica) - Instituto Oceanográfico da Universidade de São Paulo, São Paulo, 2002.

VAZ-DOS-SANTOS, A. M. Identificação de estoques da merluza, Merluccius hubbsi Marini, 1933 (Gadiformes: Merlucciidae) na Região Sudeste-Sul do Brasil. 2006. 196 p. Tese (Doutorado em Oceanografia Biológica) - Instituto Oceanográfico da Universidade de São Paulo, São Paulo, 2006.

(Manuscript received 17 January 2008; revised 14 April 2008; accepted 01 September 2008) 